\title{
Environmental Sanitation in the KOTAKU Program Area in Kendari City
}

\author{
La Ode Ali Imran Ahmad, Ramadhan Tosepu ${ }^{2}$ \\ \{imranoder@gmail.com ${ }^{1}$, ramadhan.tosepu@uho.ac.id ${ }^{2}$ \} \\ ${ }^{1,2}$ Faculty of Public Health, Halu Oleo University Kendari, Indonesia
}

\begin{abstract}
One form of resource management implemented by the Kendari City government by creating various programs that are directly empowered by the community is the KOTAKU (No Slum City) program. The KOTAKU program in the city of Kendari has been implemented since 2015 with a target of 100 percent sanitation, clean water meeting the requirements and 0 percent of slums. The purpose of the research is to find out the description of the primary sanitation system, community behavior and the empowerment model of the city of Kendari. The type of this research is descriptive survey research obtained by the results of water quality there are 309 $(81.3 \%)$ respondents who meet the requirements, $60.5 \%$ come from well drilled. Wastewater management 65 respondents use a septic tank. Dumping rubbish 127 respondents threw on the yard then burned. Three hundred one respondents who used the type of discharge of gooseneck feces. One hundred eighty-five respondents who use a semi-permanent kind of house. In conclusion, the condition of water sanitation in Kendari City is seen from the quantity and quantity fulfilling the requirements.
\end{abstract}

Keyword: KOTAKU, Sanitation, Environment, Community, Indonesia.

\section{Introduction}

One form of resource management implemented by the Kendari City government by creating various programs that are directly empowered by the community is the KOTAKU (no slum in the city) program. The KOTAKU program in the town of Kendari has been implemented since 2015 with a target of 100 percent sanitation, clean water meeting the requirements and 0 percent of slums [1].

In 2015, the number of villages that carry total sanitation based on the community or STBM program was 42 villages and increased to 48 districts in 2016. In pursuit of this, there are still some obstacles faced including changes in behavior and the achievement gap villages which STBM implement.

The achievement gap of the STBM village is caused by not all officers reporting the results of activities in their working area. Drinking water that is safe for health is drinking water that meets physical, microbiological, chemical and radioactive requirements [2]. Physically, healthy drinking water is odourless, tasteless, colourless and has total dissolved solids, turbidity, and temperature according to the specified threshold [3]. In Kendari City is included in the excellent category.

In Kendari City the percentage of residents who have access to decent drinking water in 2016 was $82.51 \%$. The highest rate of latrine use for families who have access to proper sanitation is the work area of Jati Raya Health Center is $71.69 \%$, and the lowest percentage of 
use of care that has access to adequate sanitation is the working area of Nambo Health Center at $54.14 \%$ [4].

\section{Methods}

This type of research is descriptive survey research with a population of all communities using the Proposal Sampling technique. Data collection uses secondary data and primary data.

\section{Results}

Water quality is a measure of water conditions seen from physical, chemical, and biological characteristics. Water quality also shows the size of water conditions relative to the needs of aquatic biota and humans [5]. Clean water is one type of water-based resource that is of good quality and commonly used by humans for consumption or in carrying out their daily activities including sanitation.

Table 1. Distribution of Respondents Based on Water Quantity and Water Resources in the Region Slum Kendari, $n=380$.

\begin{tabular}{lcc}
\hline \multicolumn{1}{c}{ Item } & \multicolumn{2}{c}{ Total } \\
\cline { 2 - 3 } & n & \% \\
\hline Clean Water Quality & 297 & 78.2 \\
Qualify & 83 & 21.8 \\
$\quad$ Not eligible & & \\
Source of Clean Water & 91 & 23.9 \\
Plumbing & 230 & 60.5 \\
Drilling Well & 50 & 13.2 \\
Water springs & 6 & 1.6 \\
Rainfed & 3 & 0.8 \\
River & & \\
\hline
\end{tabular}

Table 1 shows that out of 380 respondents based on the quantity of water, 297 respondents have a quantity of water fulfilling the requirements $(78.2 \%)$, and 83 respondents are having an amount of water that does not meet the criteria $(21.8 \%)$. Of the 380 distribution respondents based on clean water sources, the majority of respondents obtained from drill wells which were $230(60.5 \%)$ and a small portion came from rivers, namely $3(0.8 \%)$.

Table 2. Distribution of Respondents by Type of Waste Water Disposal, Septic Tanks for Wastewater and Open Channels for Disposal of Wastewater in Slum Areas of Kendari City.

\begin{tabular}{lcc}
\hline \multicolumn{1}{c}{ Item } & \multicolumn{2}{c}{ Total } \\
\cline { 2 - 3 } & $\mathbf{n}$ & $\mathbf{\%}$ \\
\hline Types of Waste Water Disposal, $n=380$ & 60 & 15.8 \\
Riol system to river & 65 & 17.1 \\
$\quad$ Septic Tank & 46 & 12.1 \\
$\quad$ Hole without lid & 125 & 32.9 \\
$\quad$ Open channel to ditch & 84 & 22.1 \\
Discarded to yards & 37 & 9.7 \\
Septic Tank Waste Water Disposal, $n=65$ & 28 & 7.4 \\
$\quad$ Qualify & & \\
$\quad$ Not eligible &
\end{tabular}




\begin{tabular}{lll}
\hline Open Water Disposal Channels, $n=125$ & & \\
Qualify & 53 & 13.9 \\
Not eligible & 72 & 18.9 \\
\hline
\end{tabular}

Table 2 shows that of the 380 distribution respondents based on the type of wastewater disposal, there were 60 respondents who had the type of sewerage with a riol system into the river $(15.8 \%), 65$ respondents had a type of wastewater disposal with a septic tank $(17.1 \%)$ 46 respondents had a kind of sewage discharge with a lid without holes (12.1\%), 125 respondents had a type of wastewater discharge with an open channel to the ditch $(32.9 \%)$, and 84 respondents had a type of wastewater disposal by being dumped into the yard $(22.1 \%)$. Of the 65 distribution respondents based on the use of septic tanks for wastewater disposal, 37 respondents were using the septic tank for eligible wastewater disposal $(9.7 \%)$, and 28 respondents were using septic tanks for wastewater disposal not fulfilling the requirements (7.4\%). Table 2 shows that of the 125 distribution respondents based on the use of open channels for wastewater disposal, 53 respondents were using the public channel fulfilling the requirements $(13.9 \%)$, and 72 respondents were using open channels that did not meet the criteria $(18.9 \%)$.

Table 3. Distribution of Respondents by Type of Waste Disposal, Types of Disposal of Feces, Model of Goose Neck for Disposal of Feces and Clay Models for Disposal of Feces in Slum Areas of Kendari City.

\begin{tabular}{|c|c|c|}
\hline \multirow{2}{*}{ Item } & \multicolumn{2}{|c|}{ Amount } \\
\hline & $\mathrm{n}$ & $\%$ \\
\hline \multicolumn{3}{|l|}{ Type of Waste Disposal, $n=380$} \\
\hline Landfill & 6 & 1.6 \\
\hline On the yards then burned & 127 & 33.4 \\
\hline Go to the Temporary Storage Place Every Day & 54 & 14.2 \\
\hline Take the Trash Officer & 12 & 3.2 \\
\hline Plastic bag & 72 & 18.9 \\
\hline Thrown into the river/sea & 45 & 11.8 \\
\hline Using the trash can & 64 & 16.8 \\
\hline \multicolumn{3}{|l|}{ Types of Fecal Disposal, $n=380$} \\
\hline Cemplung & 65 & 17.1 \\
\hline Goose neck & 301 & 79.2 \\
\hline Home yards & 3 & 0.8 \\
\hline Garden & 3 & 0.8 \\
\hline River & 8 & 2.1 \\
\hline \multicolumn{3}{|l|}{ Goose Neck Model For Fecal Disposal, $n=301$} \\
\hline Qualify & 220 & 57.9 \\
\hline Not eligible & 81 & 21.3 \\
\hline \multicolumn{3}{|l|}{ Flat Model for Fecal Disposal, $n=59$} \\
\hline Qualify & 14 & 3.7 \\
\hline Not eligible & 45 & 11.8 \\
\hline
\end{tabular}

Table 3 shows that out of 380 respondents based on the type of waste disposal, there were 6 respondents who used landfill type of waste disposal (1.6\%), 127 respondents who used the kind of garbage disposal in the yard then burned (33.4\%), 54 respondents who use the kind of garbage disposal to polling stations every day (14.2\%), 12 respondents who use this type of garbage disposal are taken by garbage workers (3.2\%), 72 respondents who use a type of plastic bag waste disposal (18.9\%), 45 respondents who used this type of waste disposal were 
disposed of into the river/sea $(11.8 \%)$, and there were 64 respondents who used this type of garbage disposal using trash cans $(16.8 \%)$. Of the 380 respondents based on the kind of feces disposal, there were 65 respondents who used the type of cemplung feces disposal (17.1\%), 301 respondents who used the type of gooseneck feces disposal $(79.2 \%), 3$ respondents who used the fecal discharge type $(0.8 \%), 3$ respondents who use the type of feces disposal in the garden $(0.8 \%)$, and there are 8 respondents who use the type of feces disposal in the river $(2.1 \%)$.

Table 3 also shows that of 301 distribution respondents based on the use of gooseneck models for feces disposal, there were 220 respondents using gooseneck models for qualifying feces disposal $(57.9 \%)$, and 81 respondents using gooseneck models for fecal discharge did not meet terms $(21.3 \%)$. Of the 59 distribution respondents based on the use of clay models for fecal disposal, 14 respondents were using the clay model for eligible feces disposal (3.7\%), and 45 respondents were using the clay model for fecal disposal not likely (11.5\%).

Table 4. Distribution of Respondents by Type of House and Knowledge in Slum Areas of Kendari City.

\begin{tabular}{lcc}
\hline \multirow{2}{*}{ Item } & \multicolumn{2}{c}{ Amount } \\
\cline { 2 - 3 } & $\mathrm{n}$ & $\%$ \\
\hline House Type, $n=380$ & 72 & 18.9 \\
Permanent & 185 & 48.7 \\
Semi Permanent & 123 & 32.4 \\
Not permanent & & \\
\hline Knowledge, $n=380$ & 55 & 14.5 \\
Well & 325 & 85.5 \\
Not good & & \\
\hline
\end{tabular}

Table 4 shows that of the 380 distribution respondents based on the type of house, 72 respondents used the kind of permanent home (18.9\%), 185 respondents used the type of semi-permanent home $(48.7 \%)$, and 123 respondents used the type of house not durable $(32.4 \%)$. Fifty-five respondents had good knowledge $(14.5 \%)$, and 325 respondents had poor knowledge $(85.5 \%$.

\section{Discussions}

Environmentally sound housing development has a positive effect on the environment. Some policies regulate the environment for housing and settlements in the City area, namely policies on housing provision and improvement, Policies on public awareness, Drinking water supply and management policies and city structuring policies and waste management policies [6]. Based on data on the condition of the existing slum area of Kendari City, the handling program will be carried out in an integrated and comprehensive manner while still considering the priority of management based on regional conditions.

The handling of environmental sanitation by the government still faces many obstacles. The number of existing facilities is not comparable to population growth. Also, the community still practices unhealthy behaviors, such as defecating in a garden or a river, washing in a river where the water is dirty, littering.

Environmental sanitation is the health status of an environment that includes housing, sewage, clean water supply [7]. A healthy home must fulfill air circulation [8]. The number of homes that do not meet health requirements is not only due to cost factors but lack of knowledge about the importance of housing facilities [9]. The more advanced the level of 
one's life, the higher the water needs. For the needs of drinking water needed an average of 5 liters/day, overall the need for water in a household is around 60 liters/day [10].

Furthermore, in terms of quality, measurements are taken by Government Regulation No. 416 of 1990 concerning Requirements and Supervision of Clean Water Quality. Humans cannot live without water; water for humans is an absolute necessity because water is a human body-forming substance that reaches $75 \%$ of the human body without fat tissue. Water supply for household needs must be sufficient, both in quality and quantity [11].

Fecal discharge is an integral part of environmental health. Disposal of feces that do not meet health requirements will facilitate the spread of disease among other things typhus, dysentery, cholera, and various kinds of worms [12]. Every family toilet must meet health requirements. Such as not polluting the soil surface around the bathroom, not contaminating surface water and groundwater, cannot be reached by insects especially flies and cockroaches and other animals do not cause odor, is easy to use, simple in design, and inexpensive. Besides, stool can be a source of disease, because the toilet disposal facilities that meet the requirements both in terms of construction and health are essential for the incidence of diseases [13].

Waste disposal is essential to note. Waste disposal sites are sought to be available in sufficient quantities and are easily accessible, closed so as not to become a place for developing various causes of disease. Good waste management, not just for health purposes, but also for the beauty of the environment [14]. Waste and its management become an increasingly urgent problem because if it is not handled correctly, it will cause a change in the balance of the environment that is detrimental or unexpected so that it can pollute the environment both to the soil, water and air [15].

Many factors play a role in the quality of environmental sanitation, one of which is the community's knowledge of environmental sanitation. Knowledge plays an important role in the quality of community sanitation [16]. If knowledge about community environmental sanitation is good, the quality of environmental sanitation will also be useful. Most of the people included in the slum area category have low knowledge of environmental sanitation, and this is also very closely related to the level of education of the community. The results of the study found that respondents who were categorized as living in slums were dominated by those who only had high school and junior high school education levels. Whereof the 380 respondents there were 174 respondents with senior secondary education (45.8\%), 109 respondents had junior high school education $(28.7 \%)$, and those who had undergraduate education were 17 respondents $(4.5 \%)$ and 5 diploma educated $3(1,3 \%)$, and the rest graduated from elementary school and did not go to school. The better the community's knowledge about environmental sanitation and environmental health, the better the behavior will be in maintaining environmental sanitation [17]. Most of the respondents surveyed did not understand the various types of diseases that could arise due to poor environmental sanitation so that no preventive measures are taken to anticipate the occurrence of health problems that will occur because of the issues caused by poor environmental sanitation.

\section{Conclusion}

The condition of water sanitation in Kendari City is seen from the quantity and quantity fulfilling the requirements. The type of wastewater disposal that is widely used is an open sewer that does not meet the requirements. The landfill is still in the next yard and then 
burned. The most commonly used type of fecal disposal is the gooseneck model. The community's knowledge of environmental sanitation and disease is not good .

\section{Reference}

[1] A. R. Ramadhan, "Strategi Komunikasi Organisasi Pelaksana Program Kota Tanpa Kumuh (Kotaku) Di Kota Kendari (Studi Komunikator Pada Dinas Pupr Kota Kendari Bidang Cipta Karya)," Journal Ilmu Komunikasi UHO, vol. 3, 2018.

[2] M. Odagiri, Z. Muhammad, A. Cronin, M. Gnilo, A. Mardikanto, K. Umam, et al., "enabling factors for sustaining open defecation-free communities in rural Indonesia: a cross-sectional study," International journal of environmental research and public health, vol. 14, p. 1572, 2017.

[3] J. DeZuane, Handbook of drinking water quality: John Wiley \& Sons, 1997.

[4] D. K. Kendari, "Profile of Health Kendari," 2017.

[5] D. V. Chapman and W. H. Organization, "Water quality assessments: a guide to the use of biota, sediments and water in environmental monitoring," 1996.

[6] P. Newman, "The environmental impact of cities," Environment and Urbanization, vol. 18, pp. 275-295, 2006.

[7] R. Tosepu, "Kesehatan Lingkungan," Penerbit Bintang, Kendari, 2010.

[8] C.-E. Winslow, "Housing as a public health problem," American Journal of Public Health and the Nations Health, vol. 27, pp. 56-61, 1937.

[9] B. Starfield and L. Shi, "The medical home, access to care, and insurance: a review of evidence," Pediatrics, vol. 113, pp. 1493-1498, 2004.

[10] G. Howard, J. Bartram, S. Water, and W. H. Organization, "Domestic water quantity, service level and health," Geneva: World Health Organization 2003.

[11] M. o. Health, "Health Regulation of Indonesia," 1990.

[12] W. H. Organization, Guidelines for the safe use of wastewater, excreta and greywater vol. 1: World Health Organization, 2006.

[13] M. A. Massoud, A. Tarhini, and J. A. Nasr, "Decentralized approaches to wastewater treatment and management: applicability in developing countries," Journal of environmental management, vol. 90, pp. 652-659, 2009.

[14] T. Akter and A. Ali, "Factors influencing knowledge and practice of hygiene in Water, Sanitation and Hygiene (WASH) programme areas of Bangladesh Rural Advancement Committee," Rural \& Remote Health, vol. 14, 2014.

[15] A. Joshi, S. Prasad, J. B. Kasav, M. Segan, and A. K. Singh, "Water and sanitation hygiene knowledge attitude practice in urban slum settings," Global journal of health science, vol. 6, p. 23, 2014.

[16] H. Lestari, H. Bahar, and P. Asfian, "Environmental Risk Factors In Coastal Area of Wawatu Village, Moramo Sub District, North of South Konawe, Southeast Sulawesi," Public Health of Indonesia, vol. 3, pp. 107-111, 2017.

[17] K. Banda, R. Sarkar, S. Gopal, J. Govindarajan, B. B. Harijan, M. B. Jeyakumar, et al., "Water handling, sanitation and defecation practices in rural southern India: a knowledge, attitudes and practices study," Transactions of the royal society of tropical medicine and hygiene, vol. 101, pp. 1124-1130, 2007. 